\title{
Correction to: Spirituality
}

\section{Carl Becker}

\section{Correction to:}

\section{H. ten Have (ed.), Encyclopedia of Global Bioethics, DOI 10.1007/978-3-319-09483-0_398}

The original version of chapter, "Spirituality", was published in 2016 with exclusive rights reserved by the Publisher. It has now been converted to open access retrospectively and the copyright updated to The Author(s). It is licensed under the terms of the Creative Commons Attribution-NonCommercial-NoDerivatives 4.0 International License. The book has also been updated with this change.

The updated version of this chapter can be found at https://doi.org/10.1007/978-3-319-09483-0_398 